The 16th Economic International Conference

New Challenges and Opportunities for the Economy 4.0, May 7-8th, 2020, Suceava, Romania

\title{
Contemporary Influence on the Built Cultural Heritage. Case Study Applied in the Villages of Mureş County
}

\author{
Andreea-Oana ENACHE \\ https://doi.org/10.18662/lumproc/ncoe4.0.2020/39
}

How to cite: Enache, A.-O. (2020). Contemporary Influence on the Built Cultural Heritage. Case Study Applied in the Villages of Mureş County. In C. Nastase (vol. ed.), Lumen Proceedings: Vol. 13. 16th Economic International Conference NCOE 4.02020 (pp. 430-437). Iasi, Romania: LUMEN Publishing House. https://doi.org/10.18662/lumproc/ncoe4.0.2020/39 


\title{
Contemporary Influence on the Built Cultural Heritage. Case Study Applied in the Villages of Mureş County
}

\author{
Andreea-Oana ENACHE ${ }^{1}$
}

\begin{abstract}
The elements of cultureand local tradition are essential of the collective imaginary, but also of th enational portfolio. The discovery of the cultural heritage through techniques and methods of promotion and integration of some objectives in the tourist circuit, are for the purpose development of tourism and attracting the potential consumers of cultural heritage. The contemporary influence is encountered both in promoting the area, the tourist circuit and the business, as well as in responding to the demands of consumers of built cultural heritage. Thus, in this material, we will analyze the contemporary influences that help the development of the business and the area in which it is carried out, by applying five entrepreneurial models in several villages in Mures County.
\end{abstract}

Keywords: cultural heritage; tradition; contemporary influences; tourism.

1The Institute of Nationale Economy, Bucharest, Romania, enache_oanaa@yahoo.com. 


\section{Introduction}

The built cultural heritage is an element of great interest for the European Union, being expressed in founding texts of several Conventions, including the Hague Convention, the Athens and Venice Charters and the UNESCO Convention [1].

The tangible elements, but also the intangible ones of the heritage define the cultural history, the culture and the local tradition specific to the geographical area. Preserving heritage elements helps to create a respect for the identity and diversity of tourist areas, but also to create a sense of belonging to a community of values for tourism consumers [5].

The digitalization of the tourism sector is a contemporary influence of great interest, managing to capture both the beauty of the area of tangible heritage, houses, buildings and historical monuments, as well as those of intangible heritage, nature, landscape and local traditions [3]. By transposing these values in the online environment, it is possible to attract potential consumers of cultural heritage, forming a collective imagination by breaking down barriers of distance and language, but also attracting economic investment [2].

The digital display of cultural heritage entails an economic development of the area, by applying entrepreneurial models and by attracting investigations with public, private capital or European funds [4].

In the context of globalization, it is desired to preserve the identity of traditional villages in Romania, to be preserved, maintained and known by consumers of cultural heritage. Romania is a country with a huge cultural heritage, the villages preserving from ancient times the natural beauty of the area, an ethnic diversity in what their houses and annexes represent, but also more traditions and customs for each region [5].

\section{Theoretical Background}

Cultural tourism is an opportunity for sustainable economic development at the local level. Thus, one of the opportunities for economic development is based on forms of innovative entrepreneurship. This form of entrepreneurship promotes business models based on cooperation between stakeholders and the private partnership. Digital technology has a great impact on economic, social and cultural activities, facilitating the possibility to obtain information about heritage assets without being physically present on the spot. Technology offers young people the best solution to explore cultural heritage, online and to create new business ideas 
that capitalize on the elements of heritage. Thus, in the digital age, new active tools are emerging that have a role both in facilitating the organization of travel, but also in supporting innovative forms of cultural consumption, especially participatory [6].

\section{Argument of the paper}

\section{Contemporaty Influences - Digitization}

The European Union, through its sustainable development policies, emphasizes cultural heritage as a strategic element in the economic development of each country.

Cultural heritage has had to constantly adapt to contemporary influences, so that the recovery and valorization of the past do not oppose them, but reproduce the characteristics of the past in and for a current lifestyle, expectations and needs [7].

Marketing policies and the promotion of an area, implemented by local and government administrations, by creating a road and digital infrastructure, attract potential tourism consumers, both from the country and from abroad [8]. Facilitating access to heritage areas, preserving tangible elements with national or European funds and promoting them online, contributes to the development of the area and to attracting consumers of cultural tourism. The online promotion of cultural heritage has a great impact on young people. This promotion is made much easier through social networks, which young people access frequently [9].

The application of entrepreneurial models is also a form of contemporary influence of the valorization of the elements of cultural heritage. These entrepreneurial models are the basis of a sustainable economic development in the medium and long term of the heritage area. The development of the area is done by creating accommodation, dining spaces, workshops and other methods of learning and leisure, where other cultural activities or sports tourism circuits can be integrated [10].

\section{Arguments to support and argue the thesis}

\section{Cultural heritage built in Mureş County}

Romania is a country with a rich cultural heritage. Our country has a great cultural heritage recognized and integrated in the UNESCO world portfolio. 
Beyond modernization and industrialization, Romania has remained a country with many rural areas, where nature and the history of places intertwine, thus forming its own national identity.

The villages in Romania have an ethnic cultural diversity, which brings contributions to the national cultural heritage, through the forms of construction of houses and households, but also through customs and traditions specific to the area [11].

In this material, the contemporary influence on the cultural heritage built in Mureş County was analyzed. The villages in this county preserve the history of the past, through its houses and settlements [12].

The capitalization of these tangible elements of cultural heritage can be done by applying entrepreneurial models that respond to the requirements and desires of consumers and potential consumers of cultural tourism.

In the southern area of Mureş County, in the village of Agrişteu, in Bălăuşeri Commune, there is a traditional Romanian construction, with a history of over 150 years and which has been very well preserved by the owners over time.

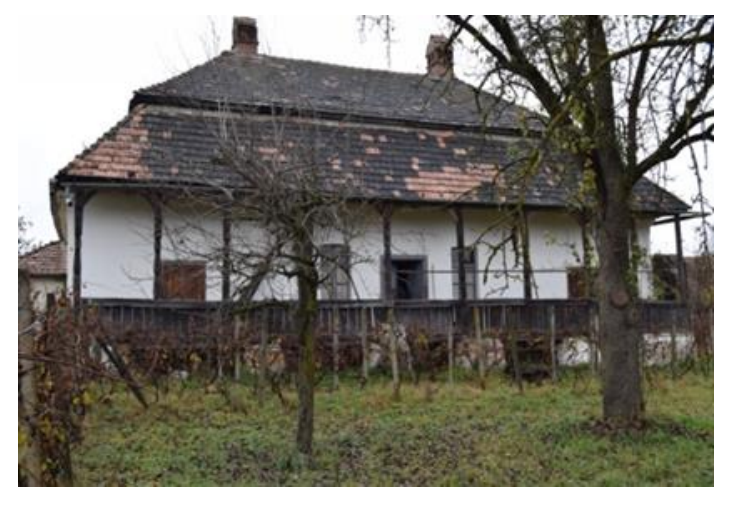

The owner of this household has developed a small business, turning the house into a tourist boarding house that offers tourists accommodation in the big house, three meals a day, which can be served in the yard or in the barn converted into dining space and also can participate in traditional events,

crafts or pottery.

Also, tourists can participate in various circuits, such as a historical circuit by discovering archeological sites within the village or a religious circuit, where they can visit the Reformed church in the village, this being a set of monuments and the Romanian Orthodox Church, both constructions being introduced in the built cultural heritage of Agrişteu Village.

The target customer segment is that of the elderly. They prefer the peace and conditions offered by a pension. Tourists are interested in knowing the history and traditions, visiting some picturesque areas, of a 
special beauty, with the traditional architecture of the houses and with ancient customs related to: port, crafts, gastronomic specialties [13].

The local authorities, by implementing the strategies for heritage protection and socio-economic development of the area, have developed a tourist network, which contributes to the consumption of cultural heritage.

All kinds of cultural events have emerged that highlight the natural beauty of the places, such as concerts, movie nights, traditional fairs and others, which capitalize on all those elements of national heritage [14].

In another area, in Glăjărie Village, from Gurghiu Commune, we meet several businesses that highlight the built cultural heritage. The houses in this village are built in Hungarian style, with an age of over 100 years and which in turn have been consolidated, preserved and transformed into small businesses that meet the requirements of consumers of cultural tourism.

In this village we met two owners who created a circuit that responds to the wishes of consumers. One of the owners offers accommodation and meals with traditional products and dishes. This type of business, we saw in the previous example, is a successful one, through the economic development of the area, by capitalizing on the heritage built by attracting consumers and by promoting the pension directly and the area, indirectly on social networks.

Another owner has developed a business that has a role in capitalizing on local traditions, where tourists see how to work a carpet in the war of weaving and can also learn these techniques.

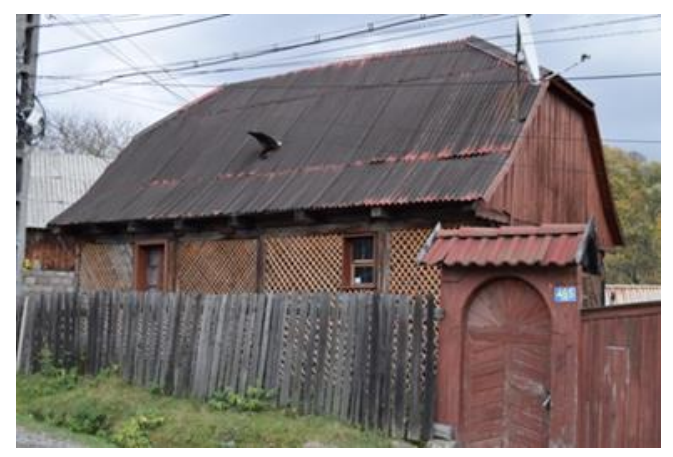

The business idea refers to the development of a museum, which offers products and services, such as: organization of exhibitions, events, presentations, leaflets, books, souvenirs. The rooms will contain various representative collections for the rural area (wooden furniture, paintings, old photos, objects from the farm). Tourists will be able to make a foray into the peasant universe of Southern Transylvania[14].

Through the development of the business, the promotion of the area, the enhancement of local riches and traditions, the increase of the level of education and culture among the inhabitants and tourists from other areas of Romania, but also from abroad, will also be pursued. 
Visiting the museum can be included in a tourist circuit that aims at several nearby objectives, located in famous localities, such as: Târgu Mureş, Sovata, Sighişoara, Alba Iulia.

The museum will highlight traditions of life and family, it has the wedding coats of the first owners, old photos, inherited from the owners.

The location will be a house-museum, with the organization of small events (sitting, poetry evening, children's story evening, demonstration workshops for preparing and baking bread and other traditional dough preparations) [12].

Targeted is the segment of consumers of cultural tourism of the second and third age. They prefer to visit museums that enhance rural civilization. Tourists are interested in knowing the history and traditions, by visiting such museums, which highlight elements of traditional architecture, folk costumes, traditional crafts, gastronomic specialties.

Another example of valorization of the built cultural heritage is found in Rîciu Village, from Rîciu Commune, where the owner of a Romanian household turned it into a digital boarding house, with automatic check-in, available online and via SMS. This business is aimed at young consumers, who, based on an access code, can escape from the modern houses in the city and experience life in the country, but with contemporary influences, this house having a Wi-Fi network and free parking [4].

The high-tech house in the rural area promotes the connection between on, nature, history and present. This property shows the simplicity, but also the beauty of life in the country, as people lived it in the past, but it also brings together the present, it was digitizations, to which the current life is closely linked [15].

The target customer segment is that of young people. They can easily adapt to the conditions offered by this fully automated guesthouse. From a financial point of view, tourists can be those with average incomes, taking into account the fact that rural tourism requires small amounts, compared to accommodation in the hotel system.

The promotion of this house is done through tourist booking sites, through the reviews that tourists leave on these sites and on social networks where young consumers post their holiday experiences.

Rural tourism has increased in Romania in recent years. There is a wide variety of accommodation throughout the country. In general, service packages are offered - accommodation and meals. There is also the possibility to organize hikes in the areas around the pension. 


\section{Conclusions}

The conservation, capitalization and promotion of the cultural heritage in these areas, in the context of the dynamics of the present is a challenge for authorities, entrepreneurs and tourists. In the digital age of globalization, the national identity of each state can be put to the test if strategies for the sustainable development of areas are not applied.

In Romania, the current society has a different behavior than a decade ago, compared to the consumption of rural tourism and the consumption of cultural heritage. This aspect, which is signaled and studied by specialists in the field, for many years in other countries, must be taken into account when deciding to apply entrepreneurial methods and marketing strategies that have the role of bringing socio-economic development area, but also an increase in the number of heritage consumers.

Marketing strategies have a major impact on human behavior and the collective imagination, and this must be exploited to promote cultural heritage among young people as well.

Currently, there are many areas that capitalize on and promote the tangible and intangible elements of heritage, both in the country and abroad, through tourists and social networks.

\section{Acknowledgement}

„This work was supported by a grant of the Romanian Ministery of Research and Innovation, CCCDI-UEFISCDI, project number PN-III-P11.2-PCCDI-2017-0884/56 PDDCI/03.04.2018., within PNCDI III”.

\section{References}

[1] Council of Europe. „Strategia patrimoniului cultural European pentru secolul XXI"; $2019 . \quad$ Available from: https://issuu.com/institutulnaionalalpatrimoniului/docs/st21-romana_final

[2] European Commission, Getting cultural heritage to work for Europe. Report of the Horizon 2020 Expert Group on Cultural Heritage. 2015; p. 1-28.

[3] Lista Patrimoniului Mondial - UNESCO, Institutul Naţional al Patrimoniului, Ministerul Culturii şi Identităţii Naționale. Available from: https://patrimoniu.ro/monumente-istorice/lista-patrimoniului-mondialUNESCO

[4] Ciurea C, Filip FG. The Role of Virtual Exhibitions in Cultural Heritage Digitization, Preservation and Valorization. Informatică Economică. 2016; 20 (4). 
[5] Vasile V, Zaman G. Migrația forței de muncă şi dezvoltarea durabilă a României. Ed. Expert; 2005. p. 123-145.

[6] Bin Y, Yeh LT. The Threshold Effects of the Tourism-Led Growth Hypothesis: Evidence from a Cross-sectional Model, Journal of Travel Research; 2016.

[7] Ciurea C, Filip FG. Validation of a Business Model for Cultural Heritage Institutions. InformaticăEconomică. 2015;19(2).

[8] Moldoveanu M, Franc V I. Marketing şi cultură. Editura Expert; 1997. p. 32-38, 40-45

[9] Zhong X, Leung HH. Exploring Participatory Microregeneration as Sustainable Renewal of Built Heritage Community: Two Case Studies in Shanghai. Sustainability; 2019.

[10] Vasile V, Login I. Innovative interpretation of cultural heritage and local sustainable entrepreneurship development. Case study on Romania In(di)visible Bucharest. European Research Development in Horizon 2020; 2013.

[11] Dore L, Crouch GI. Promoting destinations: An exploratory study of publicity programmes used by national tourism organisations. Journal of Vacation Marketing; 2003.

[12] Vasile V, Surugiu MR, Login IA, Cristea A. Changes in cultural heritage consumption model: Challenges and limits. Procedia-SBS. 2015; 188(2015); 4252.

[13] Hall D, Greg R. Tourism and sustainable community development. Second Edition. Publish Routledge; 2000. p. 137-154.

[14] Joppe M. Migrant workers: Challenges and opportunities in addressing tourism labour shortages. Tourism Management; 2012.

[15] Vasile V, Surugiu MR, Login IA, Stroe A. Innovative valuing of the cultural heritage assets. Economic implication on local employability, small entrepreneurship development and social inclusion. Procedia-SBS. 2015; 188(2015); 16-26. 